\title{
Entre el Peronismo, el tercer mundo y los usos sociales del cine. Notas sobre el Instituto de Cinematografía de la unL en 1973
}

Mariano Mestman

CONICET/ Instituto Gino Germani, Facultad de

Ciencias Sociales, Universidad de Buenos Aires.

\section{Resumen}

El artículo se focaliza en el Instituto de Cinematografía (IC) de la Universidad Nacional del Litoral (UNL), Argentina, en torno a 1973-1974, no tanto en lo referido a la organización institucional e interna sino a cuatro Palabras clave: Instituto de Cinematografía, 1973, peronismo, documental, Birri. cuestiones que lo singularizan: la asunción de nuevas autoridades alineadas con el programa de Reconstrucción Nacional del Peronismo en el gobierno; la recuperación del proyecto inicial del Instituto, el del período en que Fernando Birri lo dirigió (1956-1962); los vínculos con imaginarios y experiencias nacionales e internacionales, de América Latina y del llamado Tercer Mundo; el uso social del cine con fines educativos y políticos. El texto parte de la bibliografía existente sobre los conflictos y polémicas al interior del IC: con el director interventor durante 1969-1970, así como entre grupos de afinidad en torno al documental social, por un lado, y a la indagación de lenguajes y estéticas contemporáneas, por otro. 
Desde allí se propone una lectura del proyecto de 1973 en relación con esos y otros sucesos de los años previos y con la historia más larga del Instituto. Se anexan tres documentos internos de la gestión del IC de 1973-1974, hasta ahora inéditos.

\section{Abstract}

\section{Peronism, the Third World, and the Social Uses of Cinema. Notes about the UNL Film Institute in $\mathbf{1 9 7 3}$}

This article examines the Film Institute of the Universidad Nacional del Litoral (Argentina)in 1973 and 1974.It explores four aspects: the alignment of the new authorities with the "National ReconstructionProgram» of the Peronist government, the recovery of the original spirit of the Institute developed under the direction of Fernando Birri (1956-1962), the links with international experiences and imaginaries from Latin America and the Third World, and the social use of cinema with educational and political purposes.

The starting point of this research is a critical view of the published accounts of the institute's conflicts related to the tensions and debates between the social documentary groups and more experimental film trends. In this context, I offer a reading of the 1973 project regarding those conflicts, taking into account the history of the institute since the end of the sos. Finally, I attach three unpublished documents fromthe 1973-1974 management.

\section{Keywords:}

Film Institute, 1973, peronism, Documentary, Birri.

\section{Presentación}

La historia del Instituto de Cine (IC) de la Universidad Nacional de Litoral (UNL) es bastante conocida en lo referido a los años en que Fernando Birri lo orientó (1956-1962). Se ha escrito menos sobre los períodos posteriores de la institución, hasta su clausura entre 1975 y 1976; aun- 